\title{
Bylaag tot ,Koers." \\ DIE TAAK, GRONDSLAG EN TERREIN VAN DIE PLANTFISIOLOGIE, MET SPESIALE VERWYSING NA PLANTFISIOLOGIESE NAVORSING.
}

\author{
(Intreerede gehou by die aanvaarding van die professoraat in Plant- \\ fisiologiese Navorsing aan die P.U. vir C.H.O., op 28 Julie 1954, \\ deur prof. dr. P. J. Botha).
}

Die natururetenskappe is vroeër in twee groepe ingedeel, $\mathrm{nl}$. die verklarende en die beskrywende wetenskappe. Onder eersgenoemde groep het die Fisika en die Skeikunde geressorteer, terwyl die Geologie, die Plantkunde en die Dierkunde onder laasgenoemde groep geplaas is. Met die huidige stand van die wetenskap is 'n sodanige indeling nie meer moontlik nie. Die doel en strewe van alle natuurwetenskappe is nie slegs om te beskrywe, te klassifiseer en te orden nie maar ook on verklarings vir verskynsels te probeer vind. Sover dit die biologiese wetenskappe betref, word hierdie doel seker die beste in die Fisiologie en in die Erflikheidsleer, wāt as 'n selfstandige onderdeel van die Fisiologie beskou moet word, verwesenlik. Soos ek straks sal aandui, is die Fisiologie beslis ' $n$ wetenskap wat verklarend van aard is. Dit geld vir alle afdelings van die Fisiologie, dus ook vir die Plantfisiologie.

\section{Taak en Hulpwetenskappe.}

Die Fisiologie word gewoonlik omskrywe as die wetenskap wat die lewensfunksies en -prosesse ondersoek, beskrywe en verklaar. In sy sogenaamd neutrale vorm trag dit om die lewensfunksies en -prosesse terug te voer tot bekende natuurprosesse van die anorganiese wêreld. Net soos die Fisika en die Skeikunde ondersoek dit die oorsake van verskynsels en is derhalwe ' $n$ wetenskap met 'n kousale probleemstelling. Verder is dit ook, net soos die Fisika en die Skeikunde, 'n eksperimentele wetenskap, d.w.s. dit maak van proefneming gebruik om sy gegewens in te win.

Die opvatting dat die lewensprosesse aan dieselfde fisies-chemiese beginsels as die lewelose natuur onderhewig is, het gelei tot 'n uitgebreide toepassing van die metodes van die Fisika en die Skeikunde in die 
eksperimentele Fisiologie, asook tot die vertolking van die lewensfunksies en -prosesse in terme vań hierdie twee wetenskappe. Die Fisika en die Skeikunde is dan ook die twee vernaamste hulpwetenskappe van die Fisiologie. 'n Derde belangrike hulpwetenskap van die Fisiologie is die Wiskunde. Net soos in die Fisika en in die Skeikunde word die gegewens wat deur die Fisiologie ingewin word, heel dikwels in die vorm van getalle, hetsy telgetalle of meetgetalle, of in die vorm van formules uitgedruk. Daarbenewens word een van die jongste vertakkings van die Wiskunde, nl. die Statistiese Wiskunde, tans in die Fisiologie ook steeds meer en meer toegepas. Een van die mees opvallende verskynsels wat die bioløog oral in sy ondersoekingswerk teëkom, is variasie. Vanweë hierdie feit kan die gegewens wat deur die Fisiologie ingewin word, nie so eksak soos dié van die anorganiese wetenskappe wees nie. Sowel by die beplanning van sy proewe as by die ontleding van sy gegewens kan die Statistiek gevolglik vir die fisioloog 'n baie belangrike hulpmiddel wees.

Wat die ander onderafdelings van die Biologie betref, staan die Morfologie (die leer van die struktuur van organismes) baie na aan die Fisiologie. Tussen struktuur en funksie bestaan daar steeds 'n baie noue wisselwerking, en sonder 'n behoorlike kennis van die struktuur van organismes kan ons geen deeglike begrip van hul funksie vorm nie. Waar die Morfologie egter hoofsaaklik beskrywend van aard is, is die Fisiologie, soos reeds aangedui, verklarend van aárd. Ook die Ekologie (die studie van die verhouding tussen die organisme en sy omgewing) staan in ' $n$ noue betrekking tot die Fisiologie, terwyl die Sistematiek beskou kan word as die moederwetenskap van die Biologie, 'n sekere kennis waarvan vir die beoefening van feitlik alle onderafdelings van die Biologie as voorvereiste gestel moet word.

\section{Grondslag.}

Soos uit ons inleidende omskrywing blyk, is die studieobjek van die Fisiologie die lewensfunksies en -prosesse. Die lewe staan dus in die brandpunt van die fisiologiese navorsing. Vra ons ons egter af wat onder "lewe" verstaan word, dan besef ons dadelik dat ons hier met 'n uiters moeilik definieerbare begrip te doen het. Daar bestaan verskillende opvattings oor die aard van die lewe, sommige waarvan seker so oud soos die mensdom self is. Onder die bioloë was daar egter veral twee denk. rigtinge wat opgang gemaak het, nl. die meganisme en die vitalisme. Albei hierdie strominge het hul wortels in die Griekse filosofie. 
Von Bertalanffy (1932, p.55) meen dat dit die groot Franse filosoot Decartes was wat teen die middel van die $17 \mathrm{e}$ eeu die meganistiese opvatting in die natuurwetenskap ingevoer het, en wel deur sy begrip van die sogenaamde bete machine (masjiendier). Hy het die organisme as 'n masjien beskou wat, hoewel dit baie ingewikkelder saamgestel is, tog vergelyk kan word met 'n masjien wat deur die mens vervaardig is. As gelowige lidmaat van die Kerk het hy egter 'n grens getrek vir dic toepassing van hierdie begrip, nl. by die mens. Die mens het vir hom 'n vrye wil besit wat nie an die gewone natuurwette onderworpe is nic. Hierdie grenslyn is egter deur die Aufklärung uitgewis. Chevalier de la Mettrie het naamlik in 1748 die begrip homme machine (masjienmens) naas Descartes se bète machine gestel. Alle organismes, insluitende die mens, is as hoogsingewikkelde masjiene beskou wat eenvoudig deur die kousaliteitswette van die lewelose natuur beheer word en wat deur geen besondere kragte of vermoëns van die anorganiese wêreld onderskei kan word nie.

Hierdie meganistiese opvatting van die lewe het deur die ontdekkings van die 19de eeu steeds meer en meer veld gewen en veral in die Biologie en in die Sielkunde 'n groot houvas op die wetenskaplike denke verkry. Soos ek straks sal aandui, speel dit tans nog die oorwegende rol in die Biologie.

Nieteenstaande die groot aanhang wat die meganisme verkry het, was daar tog altyd denkers, nie alleen onder die filosowe nie maar ook onder die bioloë, wat dit nie as die enigste en algenoegsame verklaring van die lewensverskynsels kon aanvaar nie, en wat trouens ook gemeen het dat die wesenlike van die lewe glad nie deur die meganisme gevat of verklaar kan word nie. Onder hierdie groep het die vitaliste 'n prominente plek beklee.

Die ouere vitaliste het geglo aan die bestaan van 'n besondere lewenskrag wat in elke organisme werksaam sou wees en wat hulle naas dic bekende kragte van die anorganiese wêreld as verklaringsgrond vir dic lewe gestel het. Hulle was daarvan oortuig dat die wesenlike trekke van die lewe tot hierdie lewenskrag teruggevoer moet word, en het alle onverklaarbare lewensverskynsels tot die lewenskrag herlei. So byvoorbeeld het hulle aanvanklik geglo dat die Fisika en die Skeikunde nooit daarin sou slaag om organiese stow we sinteties voort te bring nie. Toe Wöhler in 1828 egter daarin geslaag het om ureum sinteties te berei en die Organiese Skeikunde kort daarna geweldig opgang begin maak het, sodat 
daar naderhand 'n groot aantal organiese verbindings bekend was wat sinteties in die laboratorium berei kon word, moes hierdie idee prysgegee word. Ook ander lewensverskynsels wat die vitaliste aan hul lewenskrag toegeskryf het, is later met behulp van die Fisika en die Skeikunde bevredigend verklaar, en daardeur is baie gevoelige slae aan die vitalisme toegedien. Die opvattings van die ouere vitaliste het gevolglik naderhand heeltemal onhoudbaar geword.

Onder die neovitaliste is Driesch sekerlik die belangrikste figuur, en ons sal ons by hom as voorbeeld van hierdie rigting beperk. Net soos die meganiste verwerp Driesch die opvattings in verband met die bestaan van 'n lewenskrag. Hy is egter daarvan oortuig dat die lewe nie bloot fisies-chemies verklaar kan word nie maar aan 'n eie soort kousaliteit onderworpe is, wat hy as "Ganzheitskausalităt" naas die meganistiese "Einzelkausalitat" stel. Hy meen dat daar in elke organisme 'n onbekende faktor werksaam is wat die stoflike gebeure in die organisme reël en beheer, sodat die lewensprosesse nie in enige rigting verloop nie maar steeds sodanig dat hulle tot die totstandkoming en behoud van die geheel lei. Hierdie onbekende faktor het hy met die term "entelechie" aangedui. Driesch voer 'n hele aantal ,bewyse" aan, o.a. ook sekere eksperimentele bevindings uit sy proewe op see-egeleiers en -kieme, om aan te toon dat die lewensverskynsels nie bloot fisies-chemies verklaar kan word nie en dat daar so iets soos ' $n$ entelechie moet bestaan. Op die besonderhede van hierdie „bewyse" kan ons hier nie ingaan nie. Ons vermeld slegs dat Hartmann (1933) en andere op 'n onweerlegbare wyse aangetoon het dat Driesch se „bewyse" almal onaanvaarbaar is en dat sy opvatting daarmee ook as ongegrond beskou moet word.

Die vitalisme is derhalue sowel in sy ouere as in sy nuwe vorm, soos deur Driesch e.a. gehuldig, deur die Biologie verwerp. Von Bertalanffy (1949, p.21) gaan selfs sover on te beweer: „Die Widerlegung des Vitalismus ist die Geschichte der Biologie. Denn diese zeigt, dass immer jene Erscheinungen als Domäne vitalistischer Faktoren aufgefasst wurden, die biem jeweiligen Stand der Forschung unerklärlich schienen ...." Dic groot verdienste van die vitalisme is egter geleë in sy kritiek op dic mcganisme; in sy opvatting dat die wesenlike van die lewe nie op 'n bloot fisies-chemiese grondslag verklaar kan word nie. Hierdie denkrigting kon egter nie daarin slaag om 'n bevredigende alternatief vir die meganisme aan te bied nie.

As die Biologie reeds vroeër oorwegend materialisties georiëntee was, dan het dit met cie oorwinnings wat die meganisme oor die vitalisme 
behaal het, nog verder in die materialisme verval. Trouens, die meganisme is maar een aspek van die materialistiese siening van die werklikheid, soos uit die volgende omskrywing van die materialisme blyk: Die inaterialisme is die denkrigting wat eerstens die idee huldig dat alles in die heelal uiteindelik bestaan uit dinge wat stoflik van aard is, en tweedens glo dat alle gebeure in die natuur onderworpe is aan die wette wat die materiële dinge beheer (vgl. Joad, 1948, p. 497).

Een van die vernaamste uitlopers van die materialisme in die Biologie is die evolusionisme. In sy radikaalste vorm hou die evolusieleer streng aan die stoflike vas en trag dit om fisies-kousale verklarings te gee vir alle probleme in verband met die ontstaan van die lewe en die ontwikkeling daarvan tot die veelheid van die lewensvorme waarmee ons vandag bekend is. Die doelmatigheid van die lewensvverskynsels word toegeskryf bloot aan toevallige veranderings (mutasies) en daaropvolgende natuurlike seleksie in die stryd om die bestaan.

Vir die volslae materialis bestaan daar slegs materie en die wette wat die materiële dinge beheer. Hy beskou dus 'n deel van die werklikheid, nl. die stoflike deel daarvan, as die hele werklikheid.

Dat die materialisme so 'n sterk houvas op die natuurwetenskaplike denke gekry het, hoef ons glad nie te verbaas nie. Joad (1948, p. 495) beweer selfs: „Materialism is . . . . the natural, indeed it is the inevitable, creed of men of science. Scientists, that is to say, in so far as they confine themselves to the assertion of those conclusions and only those conclu. sions which science justifies, inevitably adopt a materialistic outlook." Hy stel dit moontlik 'n bietjie skerp, maar dit is in elk geval 'n feit dat natuurwetenskaplikes in die algemeen sterk geneig is om 'n materialistiese lewensbeskouing toegedaan te wees. Hierdie feit moet myns insiens aan die beperktheid van ons wetenskapsbeoefennig toegeskryf word. Ons kan alleen die stoflike onderdeel van die werklikheid met die fisiese en chemiese metodes wat tot ons beskikking is, enigermate ondersoek en verklaar, en daardeur loop ons gevaar dat ons te veel waarde aan die stoflike sal toeken. Bruin (1932, p. 162) het myns insiens heeltemal gelyk as hy beweer: „Een physicus loopt kans om in de wereld niets dan stof te zien, reeds door zijn beperktheid als mensch. Waar we dagelijks mee werken, dat wordt voor ons zoo licht het eenige werkelijk bestaande, in clk geval het belangrijkste in de geheele wereld." Hierdie bewering is sekerlik ook op die hedendaagse bioloog van toepassing.

Sowel van wysgerige as van natuurwetenskaplike kant het verskeie moderne denkers reeds bedenkings teen die streng materialistiese 
opvatting van die lewe geopper en trouens ook op die onhoudbaarheid van hierdie denkrigting gewys. Ek verwys 'slegs na enkeles onder hulle, nl. Bergson (1907), wat die werklikheid beskou as die beliggaming van 'n immanente beginsel van lewende verandering, die sogenaamde élan vital; Smuts (1927) e.a. met hul holistiese opvatting van die werklikheid en Von Bertalanffy (1932 en 1949), wat die opvattings wat op die analitiessummatiewe metode berus, as afdoende verklaring van die werklikheid verwerp en in die plek daarvan sy organismiese opvatting stel. Om elkeen van hierdie denkrigtings krities te ontleed, sou ons te ver wegvoer. Ek volstaan met die aandag daarop te vestig dat al hierdie strominge sterk subjektief gekleur is in die sin dat elkeen van hulle van een of ander beginsel, waaraan hy in sy ervaring voorkeur gee, uitgaan en bowendien hierdie beginsel, nieteenstaande die onselfgenoegsame aard daarvan, as algenoegsame verklaringsgrond opvat en dit sodoende verabsoluteer.

Watter standpunt neem die Christelike wetenskap nou ten opsigte van al hierdie strominge in? Twee van die vernaamste beginsels waarvan die Christelike wetenskap uitgaan is (1) dat God, die Skepper van die heelal, die enigste algenoegsame en absolute verklaringsgrond van alle dinge, dus ook van die lewe, is, en (2) dat God 'n oorspronklike verskeidenheid in (lie kosmos geskape het-dat daar dus byvoorbeeld tussen die anorganiese wêreld en die orgarismes 'n wesensverskil bestaan. Teenoor die tans nog oorheersend materialistiese denkrigting is die standpunt van die Christelike bioloog op grond hiervan dat die lewe nie gcheel cn al in terme van materie en die fisies-kousale wette van die stoflike wêreld verklaar kan word nie. Hoewel die lewe deur die stoflike gredra word en baie lewensverskynsels gevolglik mede deur hul fisies-chemiese substraat bepaal word, is dit tog iets eiesoortigs wat wesenlik van die materiële dinge verskil. Die lewe vorm 'n hoër werklikheidskring en is sodanig met die laer werklikheidskring, nl. die stoflike, vervleg dat die twee saam 'n heeltemal nuwe struktuurgeheel openbaar.

Waar die Christelike bioloog van bogenoemde beginsels uitgaan, besef hy nogtans dat hy deur sy wetenskap geen bewys vir die bestaan van God kan lewer nie. Dat God wel bestaan, is vir hom 'n saak van die geloof, en hierdie geloof vorm die grondslag van sy hele lewens- en wêreldbeskouing--dus ook van sy wetenskaplike denke. Die Christelike wetenskap is deur die feit dat dit op 'n religieuse grondslag berus, egter geen uitsondering onder die wetenskappe nie, want alle wetenskap, ook die sogenaamd neutrale wetenskap, is in laaste instansie religieus gefundeer, deurdat dit op grondbeginsels bou wat wesenlik religieus van aard 
is. Die Christelike wetenskap verskil egter in die belangrike opsig van die ander wetenskaplike stelsels dat dit alleen God as algenoegsaam en absoluut beskou en weier om enige onderdeel van die geskape werklikheid, hetsy die materie, hetsy die lewe, hetsy die psigiese of watter ander onderdeel ook al, te verabsoluteer.

Die Christelike bioloog sien dus die lewe as 'n eiesoortige skepping van God. Vir hom het die lewe nie maar deur die willekeurige spel van outonome faktore op 'n toevallige wyse uit die lewelose stof ontstaan nie. God het eers die hemel en die aarde met al die stowwe waaruit dil bestaan, geskape, en daarna het $\mathrm{Hy}$ die lewedraende inaterie (protoplasma) uit die stoflike geformeer. In hierdie lewendraende stof het Hy bepaalde funksies gelê, nl. dic van stof- en energiewisseling, dic van groci, ontwikkeling en voortplanting en die van beweging. (God het ook nie slegs een organismetipe geskape nie maar 'n hele aantal, wat, soos Lever (1952, p.22) dit uitdruk, ,gevormd werden naar een bepaald bouw- en functicplan toe, dat niet door allerlei factoren buiten Gods wil om fundamentecl gewijzigd kan worden". Hoewel daar geen fundamentele wysigings by die verskillende organismetipes kan intree nie, het God tog in hulle die vermoë gelê om deur mutasie op 'n wetmatige wyse te kan verander. Uit die eerste lewensvorme het daar op dié wyse die ryke verskeidenheid van organismesoorte, soos ons hulle tans ken, ontstaan. In elkc soort het die fundamentele bou- en funksieplan van die oorspronklike tipe cgter behoue gebly.

Vir die Christelike bioloog het die wette, die orde, die sin en die doel wat hy by sy bestudering van die lewe teëkom, nie maar deur die toeval of deur die willekeurige werking van 'n blinde noodlot ontstaan nie, maar hierdie verskynsels is volgens sy opvatting deur God self in die lewe gelê. So gesien, word die hele lewe vir hom 'n openbaring van die alınag van God en sy vakgebied die terrein waarop hy die wondere van Gods skepping kan bestudeer.

Waar die Christelike wetenskap op hierdie grondslag gefundeer is, beteken dit nie dat hy alle bevindings en opvattings van ander wetenskaplike stelsels verwerp nie. Inteendeel, die Christelike wetenskaplike aanvaar die waarheidselemente van ander stelsels en plaas hulle in hul regte verband in sy eie. Die Christelike ondersoeker pretendeer ook nie om in sy wetenskapsbeoefening volmaak te wees nie. Sy arbeid is ook maar menslike arbeid met al die swakheid en gebreke wat mensewerk aankleef. Hy moet derhalwe ook gedurig teen wanpraktyke en gevare waak, waarvan ek hier slegs twee wil noem, wat myns insiens van be- 
sondere belang is. In die eerste plek moet ons as Christenbioloë oppas dat ons ons nie op 'n soortgelyke wyse as die vitaliste vasloop nie. As ons biologiese probleme teëkom waarvoor ons geen verklaring kan gee nie, mag ons hulle nie, deur hulle tot God terug te voer, as afgedaan beskou nie. So 'n houding kan maklik op 'n verwarring van wetenskaplike luiheid met Christelike vroomheid neerkom en sal nie alleen stremmend op die ontwikkeling van ons wetenskap werk nie maar ook in stryd wees met die kultuurgebod wat God aan die mens gegee het, nl. om die aarde te onderwerp en daaroor te heers. Waar God aan ons die gawe geskenk het om wetenskaplike werk te kan verrig, eis $\mathrm{Hy}$ dat ons hierdie talent nie in 'n sweetdoek sal toedraai nie maar daarmee sal woeker, selfs al is ons vermoëns beperk en al sal ons kennis altyd maar ten dele bly. In die tweede plek mag ons nooit skroom om wetenskaplike feite wat voldoende deur ondersoek gefundeer en bewys is, vrymoediglik te aanvaar nie. Dit het reeds meermale gebeur dat wetenskaplike feite wat aanvanklik as in stryd met die Bybel beskou is, later heeltemal in ooreenstemming met die Skrifwaarhede gebring kon word. Ons kan volmondig met Lever $(1953$, p.7) saamstem waar hy opmerk: „En hij (die Christennatuurondersoeker) zal omdat alle feiten welke de natuurwetenschap te voorschijn brengt elementen van Gods Schepping zijn deze eerbiedig moeten accepteren en nimmer loochenen of verdraaien".

\section{Terrein.}

Soos algemeen bekend is, word die Fisiologie in drie afdelings ingedecl, nl. Plantfisiologie, Dierfisiologie en Menslike Fisiologie. Hierdie afdelings vorm egter geen afgeslote eenhede nie. Daar kom talryke probleme voor, veral van 'n biochemiese aard, wat vir elkeen van die drie afdelings van naasteby ewe groot betekenis is. Die gegewens wat in een afdeling ingewin word, en die opvattings wat daar ontwikkel word, word dan ook gedurig aangevul deur gegewens en opvattings uit die ander twee afdelings. Op dié wyse werk die drie oor en weer bevrugtend op mekaar in.

Die Plantfisiologie beperk sy studieterrein in elk geval hoofsaaklik tot die lewensfunksies en -prosesse by plante. Net soos in die ander twee afdelings van die Fisiologie kan hierdie terrein in drie onderafdelings verdeel word, nl. (a) stof-en energiewisseling, (b) vormwisseling en (c) plekwisseling.

(a) Stof- en energiewisseling: Die liggaam van 'n lewende plant bestaan nie uit 'n eendersblywende stofmassa nie. Dit neem gedurig 
stowwe uit die omgewing op, verwerk hulle tot verbindings wat vir die lewensbedrywighede van die plant bruikbaar is, en gee ook gedurig stowwe aan die omgewing af. Hierdie stofwisselingsprosesse gaan gepaard met energiewisseling. Die eerste onderafdeling van die Plantfisiologie dek die hele studieterrein in verband met die fisiese en chemiese prosesse wat by die opname, vervoer, verwerking en afgee van stowwe by plante betrokke is, asook die daarmee gepaard gaande verskynsel van energiewisseling. Dit bestudeer: die opname, vervoer en afgee van water deur plante; die opname, vervoer en fisiologiese betekenis van die mineraalvoedingstowwe; die opbou van organiese voedingstowwe uit eenvoudige verbindings, soos koolsuurgas en water (fotosintese); die verandering van organiese voedingstowwe deur vertering en die oksidasie van organiese stowwe in die plantliggaam (asemhaling).

Die stofveranderingsprosesse word met die term metabolic aangedui, en hieronder word twee tipes prosesse onderskei, nl. opbouprosesse en afbouprosesse. Onder die opbouprosesse is fotosintese van primêre belang, want dit is die aanvangsproses vir die sintese van alle organiese stowwe in plante. Deur hierdie proses word ligenergie opgeneem en in die vorm van chemiese energie vasgelê. Die afbouprosesse bestaan hoofsaaklik uit vertering en asemhaling. Deur laasgenoemde proses word die energie wat tydens fotosintese vasgelê is, vrygestel, en hierdeur word die lewensbedrywighede van die plant in stand gehou.

Sowel fotosintese as asemhaling is uiters ingewikkelde biochemiese prosesse in verband waarmee daar nog baie onsekerheid bestaan. Omdat hulle van besonder groot fisiologiese betekenis is, staan hierdie twee prosesse in die brandpunt van die moderne fisiologiese navorsing en word hulle met sulke resente tegnieke, soos dic gebruik van radioaktiewe isotope, bestudeer.

(b) Vormwisseling (groei, ontwikkeling en voortplanting): Veral in die jong lewenstadium is die stofwisseling gewoonlik sodanig dat die stofopname die stofverlies oortref. Die massa en volume van die plant neem gevolglik toe, m.a.w. dit groei. Daarbenewens vind daar sekere wetmatige inwendige veranderings plaas wat 'n geleidelike verandering in die struktuur en vorm van die plant bewerkstellig en wat as ontwikkeling bekend staan. As die plant 'n sekere ontwikkelingstadium bereik, gaan dit oor tot die voortbrenging van nuwe individue, d.w.s. voortplanting vind plaas. Groei, ontwikkeling en voortplanting is verskyırsels wat baie kenmerkend van organismes is. Hierdie drie verskynsels word sowel 
deur uitwendige as inwendige faktore sterk beïnvloed. So byvoorbeeld is deur die moderne navorsing aangetoon dat hormone en vitamiene 'n groot rol by die groei van plante speel, dat die ontwikkeling blykbaar ook onder beheer van hormone geskied en dat die vegetatiewe groei, ontwikkeling en voortplanting van sekere hoër plante sterk deur die relatiewe lengte van die dag en die nag beïnvloed word.

Onder hierdie onderafdeling van die Plantfisiologie ressorteer ook die studieterrein wat handel oor die oordrag van erflike eienskappe van ouerplante op hul nakomelinge. Hierdie terrein van die kennis, nl. die Erflikheidsleer (Genetika), het sedert die belangrikheid van Mendel se bevindings en gevolgtrekkings aan die begin van die huidige eeu ingesien is, met rasse skrede ontwikkel en saam met die ooreenstemmende onderafdeling van die Dierfisiologie tot 'n selfstandige wetenskap uitgegroei.

(c) flekwisseling (beweging): Die vermoë oil te kan beweeg kon! by alle organismes voor, maar by diere en die mens is dit baie meer opvallend as by plante. Slegs sommige mikropiante (wiere, swamme en bakteripë) is in stajt om soos diere van plex tot plek voort to beweeg By hoër plante kom daar in die algemeen slegs beweging van die plantorgane van een posisie na 'n ander voor. Laasgenocmde bewegings hang by plante gewoonlik baie nou met die groeiproses saam, geskied langsaam, maar word tog sterk deur uitwendige faktore, soos byvoorbeeld lig en swaartekrag, beïnvloed. Die taak van die bewegingsfisiologie is om die fisiese en chemiese verskynsels wat aan die bewegingsvermoë ten grondslag lê, te verklaar.

Daarmee is in hooflyne die terrein van die Plantfisiologie afgebaken. Weens tydgebrek moet ek met hierdie beknopte oorsig volstaan. Die Plantfisiologie is egter een van die afdelings van die Biologie wat gedurende die afgelope twintig, dertig jaar met rasse skrede ontwikkel het en waarin daar tans dwarsoor die wêreld teen 'n hoë tempo verdere navorsing verrig word. Die mens trag inderdaad om met behulp van die moderne fisiese en chemiese tegnieke wat tot sy beskikking is, tot aan die uiterste grense van die fisiologiese prosesse in te dring. In feitlik alle onderafdelings van die Plantfisiologie is daar dan ook gedurende dic afgelope dekades belangwekkende ontdekkings gemaak. Om aan $u$ 'n beeld van selfs die belangrikste resente bevindings binne die bestek van 'n enkele voordrag te gee, sou 'n onbegonne tak wees. Ek sal derhalwe maar volstaan deur kortliks melding te mak van die plantfisiologiese navorsing wat an ons eic Universiteit verrig word. 


\section{Plantfisiologiese Navorsing aan die P.U. vir C.H.O.}

Daar is met die plantfisiologiese navorsing aan hierdie Inrigting veral twee rigtings ingeslaan, nl. (1) fisiologiese ondersoeke in verband met die grasveld en sy instandhouding, en (2) die fisiologie van parasitiese blomplante. Die eerste rigting hang ten nouste saam met een van Suid-Afrika se grootste nasionale vraagstukke, nl. veld-, grond- en waterbewaring. Met groot erkentlikheid moet vermeld word dat ons vir die uitvoer van hierdie werk reeds ' $n$ hele aantal jare lank finansiële ondersteuning van die Landboudepartement ontvang. Die werk is en word nog steeds met die hulp van nagraadse studente uitgevoer. Die doel daarvan is tweërlei. In eerste instansie trag ons om daarmee 'n bydrae tot die oplossing van die groot probleem van die beheer en instandhouding van ons natuurlike bodembedekking te lewer; en in die tweede plek beoog ons daarmee die opleiding van jong navorsers, waaraan daar op hierdie gebied 'n groot tekort in ons land bestaan. Die navorsing is en word hoofsaaklik op mesofitiese grassoorte uitgevoer, en wel ten opsigte van die volgende aspekte; ontwikkeling en voortplanting (stuifmeelontkieming, saadproauksie en fotoperiodie) saadontkieming, kiemplantvestiging, voedingsfisiologie, wortelgroei en -ontwikkeling, transpirasie, verwelking, droogtebestandheid, fotosintese, respirasie, lig- en skaduweeliewendheid en die invloed van edafiese faktore. Verder is daar ook aandag geskenk aan sekere gifplantsoorte, nl. die Vomeerbos (Geigeria passeneroides) en Senecio retrorsus wat as indringingsgewasse in sekere streke 'n groot bedreiging vir die veeboerdery geword het.

Die tweede navorsingsrigting, $\mathrm{nl}$. die fisiologie van parasitiese blonlplante, is die terrein waarop my persoonlike navorsing toegespits is. Met groot dankbaarheid wil ek graag vermeld dat die Wetenskaplike en Nywerheidsnavorsingsraad nou reeds 'n aantal jare lank finansiële ondersteuning by die uitvoer van hierdie werk verleen. Die aanvanklike doel wat met hierdie werk beoog is, was suiwer wetenskaplik, maar namate die werk gevorder het, is aanknopingspunte gevind vir die bestudering van vraagstukke wat op die gebied van die toegepaste navorsing lê, en is dic werk ook in hierdie rigting uitgebrei.

Die twee parasiete waaraan tot dusver die meeste aandag geskenk is, is Rooiblom (Striga latea) en Geelblom (Alectra vogelii). Hulle ressorteer albei onder die blomplantfamilie Scrophulariaceae en is albei hemiparasiete, d.w.s. hulle is gedurende hul bogrondse stadium in staat om te fotosinteer en hul eie organiese voedingstowwe op te bou, maar 
moet hul water en mineraalvoedingstowwe uit hul gasheerplante verkry. Albei hierdie parasiete val kultuurgewasse aan. Rooiblom val naamlik somergraangewasse, soos mielies en kafferkoring, aan, terwyl Geelblom op peulgewasse, soos kafferbone en grondbone, kan parasiteer. Veral Rooiblom is van groot ekonomiese belang omdat dit jaarliks groot skade berokken aan die oes in Wes-Transvaal en sekere ander streke waar somergraangewasse verbou word.

By albei hierdie parasiete kom die verskynsel van gasheerafhanklike saladontkieming voor; die parasietsaadjies kan naamlik nie soos die van ander plante selfstandig ontkiem nie, maar ontkieming geskied alleen in die aanwesigheid van 'n chemiese stof (of stowwe) wat in uiters klein hoeveelhede deur die gasheerwortels afgegee word. Hierdie uitsonderlike ontkiemingswyse was die eerste probleem wat ondersoek is (Botha, 1948; 1950, I en II, en 1951, III). Die gegewens wat in dié verband ingewin is, het aan die lig gebring dat die ontkiemingsproses by die parasietsaad in twee fases verloop, nl. 'n eerste fase, waartydens die saad onder die invloed van klam en warm toestande (genoem ,voorbehandeling") "gevoelig" word vir die inwerking van die stof wat deur die gasheerwortels afgegee word (genoem ,gasheerfaktor"); en 'n tweede fase, wat daarin bestaan dat die kiemworteltjie onder die inwerking van die gasheerfaktor begin groei. Die veranderings van die eerste ontkiemingsfase vind nie in die afwesigheid van suurstof plaas nie en is derhalwe op een of ander wyse met die aërobe asemhaling gekoppel en gevolglik metabolies van aard. Albei fases is sterk beïnvloedbaar deur 'n hele aantal uitwendige faktore. Daar bestaan verder ' $n$ hoogs betekenisvolle wisselwerking tussen die faktore wat die eerste fase beinvloed, soos byvoorbeeld die duur en temperatuur van voorbehandeling, en dié wat die tweede fase beînvloed, soos byvoorbeeld die konsentrasie van en duur van blontstelling aan die gasheerfaktor. Hierdie en ander bevindings dui daarop dat die saadjies gedurende die eerste fase 'n stof opbou wat vir ontkieming noodsaaklik is. Die oorgrote meerderheid saadjies is egter nic in staat om hierdie stof in genoegsame hoeveelhede vir ontkieming op te bou nic, en hulle moet gevolglik 'n identiese of soortgelyke stof, nl. die gasheerfaktor, van buite bykry voordat ontkieming kan plaasvind.

Vervolgens is die aard, eienskappe en fisiologiese betekenis van die gasheerfaktor van Geelblom ondersoek (Botha, 1951, IV). Uit hierdie ondersoek het duidelik geblyk dat die stof 'n aktiveringstof („Wirkstoff”) is en dat dit blykbaar onder die groep stowwe ressorteer wat Von Euler (1938) met die term „ergone" aangedui het, d.i. stowwe waarvan nie met 
sekerheid gesê kan word of hul vitamiene of hormone is nie, omdat hulle eienskappe van albei hierdie stofgroepe besit. Ten einde hulle van andeı ergone te onderskei, het ek die term „parasitoblastiene" voorgestel om die gasheerfaktore van wortelparasiete aan te dui (Botha, 1951, IV).

'n Ander aspek van die probleem waaraan aandag geskenk is, is die fisiologiese verhouding tussen Rooiblom en sy gasheerplante veral ten opsigte van water- en voedingstofbehoeftes. Dit is 'n bekende feit dat Rooiblomplantjies reeds in hul ondergrondse groeistadium en terwyl hul nog maar betreklik klein is, groot skade aan die mielieplante waarop hul groei, berokken. Die aangetaste mielieplante bly klein, is gelerig van kleur en vertoon duidelike tekens van watergebrek, selfs in klam grond. Volgens die bevindings wat tydens die huidige ondersoek met kultuurproewe ingewin is, moet hierdie verskynsel nie daaraan toegeskryf word dat die parasiet sy gasheerplant van te veel water beroof, soos vroeër gemeen is nie, maar wel daaraan dat die parasiet die wateropname van die mielieplant strem. Verdere ondersoek in hierdie verband is tans nog aan die gang.

Sowel Rooiblom as Geelblom is gasheerspesifieke parasiete, d.w.s. hulle val slegs sekere gewasse aan. Rooiblom parasiteer, sover met sckerheid vasgestel kon word, uitsluitlik op lede van die Gramineae (gras- en graanplante), terwyl Geelblom, op weinige uitsonderings na, slegs op lede van die Papilionaceae (peulplante) waargeneem is. Gedurende dic bestudering van die ontkiemingsfisiologie het die vraag hom voorgedoen of die parasitoblastiene van hierdie parasiete slegs deur hul gasheergewasse afgegee word, dan wel ook deur gewasse waarop hul nie kan parasiteer nie (non-gasheergewasse). Saunders $(1933, \mathrm{p} .8)$ was op grond van sy bevindings die mening toegedaan dat slegs gras- en graanplante by Rooiblomsaad en slegs peulplante by Geelblomsaad ontkieming kan bewerkstellig. $\mathrm{Na}$ aanleiding hiervan en of grond van die feit dat Rooiblomsaad baie lank kiemkragtig bly, het hy geen hoë verwagtings van wisselbou as bestrydingsmaatreël vir Rooiblom gekoester nie. Uit 'n studie van die literatuur in hierdie verband was dit duidelik dat dit blykbaar nie die geval by 'n hele aantal ander wortelparasiete is nie. Ek het dit derhalwe nodig geag om hierdie probleem nog eens te ondersoek. Tydens hierdie ondersoek kon met behulp van 'n verfynde ontkiemingstegnick op 'n ondubbelsinnige wyse aangetoon word dat by sowel Rooiblom- as Geelblomsaad ontkieming bewerkstellig kon word, nie slegs met worteluitskeidings van die onderskeie gasheergewasse van hierdie parasicte nie maar ook met dié van non-gasheergewasse. In die geval 
van Rooiblom is byvoorbeeld vasgestel dat die wortels van 'n hele aantal sonneblom- en grondboonstanume asook diè van kafferbone en suikerbone die parasitoblastien van hierdie parasiet afgee. Hierdie bevinding het die moontlikheid van 'n effektiewe biologiese bestrydingsmetode ingehou. Op grond daarvan kan naamlik verwag word dat gewasse, soos sonneblom, grondbone en kafferbone, doeltreffende vanggewasse vir Rooiblom sal wees. As hierdie gewasse verbou word op grond wat met Rooiblom geïnfesteer is, kan verwag word dat hul worteluitskeidings ontkieming van die parasietsaadjies in die grond sal bewerkstellig maar dat die jong parasietplantjies spoedig na ontkieming sal doodgaan, omdat hulle nie op hierdie gewasse kan parasiteer nie. Dit sal dan tot 'n vermindering van die infestasie lei.

Hierdie moontlikheid is vervolgens deur ' $n$ veldproef wat oor drie groeiseisoene (1950-1953) gestrek het, ondersoek. Die proef is met die goedgunstige medewerking van mnr. J. Wilkens jr. op sy plaas in die Ventersdorpse distrik uitgevoer. Die landery waarop dit uitgelê is, was sodanig met Rooiblom geïnfesteer dat die mielieopbrengs daarop kort voor die aanvang van die proef slegs ongeveer 7 sak per morg bedra het. By die uitlê van die proef is die willekeurige perseelmetode gevolg. Vier persele is twee jaar na mekaar onder kafferbone gebring, vier onder sonneblom, vier onder grondbone en vier onder mielies. Die derde groejseisoen is mielies op al die persele geplant. Gedurende hierdie laaste seisoen het dit spoedig geblyk dat die wisselbou 'n baie gunstige uitwerking gehad het. Op die persele wat voortdurend onder mielies was, het die mielieplante nou baie swak vertoon en daar was 'n hoë Rooiblominfestasie. Op die ander persele het die mielies veel beter gegroei en is slegs hier en daar 'n Rooiblomplant opgemerk. Hierdie verskil is veral ook baie duidelik in die graanopbrengs van die mielies van die laaste seisoen weerspieël, wat soos volg was: geen wisselbou: gemiddeld 4.0 sak per morg; na wisselbou met kafferbone: gemiddeld 14.8 sak per morg; na wisselbou met grondbone: gemiddeld 11.4 sak per morg; na wisselbou met sonneblom: gemiddeld 10.4 sak per morg. Statistiese analise van die gegewens het aangetoon dat die wisselbou met kafferbone 'n betekenisvol hoër mielieopbrengs as enigeen van die ander behandelings opgelewer het en dat die effek van wisselbou met grondbone en wisselbou met sonneblom ongeveer ewe gunstig was. Hierdie gegewens dui in elk geval op 'n oortuigende wyse claarop dat wisselbou van groot waarde vir die beheer van die Rooiblomplaag kan wees. 
Waar ek hierbo in breë trekke aan $u$ 'n beeld probeer gee het van die navorsing wat in die Plantfisiologiese Navorsingsinstituut van die P.U. vir C.H.O. uitgevoer word, was my doel hoofsaaklik om aan te toon dat op die terrein van die Plantfisiologie sowel fundamentele as toegepaste navorsing beoefen kan word. Ek meen dat albei tipes navorsing aan ' $n$ inrigting soos die P.U. vir C.H.O. en in 'n vak soos die Plantfisiologie tot hul reg moet kom. Ons Universiteit is 'n Christelik-nasionale inrigting. Dit is dus op twee groot beginsels gegrond, nl. die Christelike en die nasionale beginsel. Wat eersgenoemde betref, het ek hierbo probeer aantoon op watter grondslag en in watter gees die Christen-fisioloog sy wetenskap beoefen. En wat die nasionale beginsel betref, meen ek dat ons Universiteit ware nasiediens kan verrig deur mee te werk aan die oplossing van die menigvuldige vraagstukke wat vir die volksbestaan en -welsyn van belang is. Twee van die allerbelangrikste vraagstukke waarmee ons volk te kampe het, is eerstens die behoud en instandhouding van ons kosbare bodembedekking, nl. die natuurlike plantegroei, en tweedens ' $n$ verhoging van ons voedselproduksie om met die bevolkingsaanwas en die toenemende industrialisasie van die land tred te hou. Die Plantfisiologie kan en moet in samewerking met ander wetenskappe, veral die landbouwetenskap, sy bydrae tot die oplossing van hierdie vraagstukke lewer.

I

Hooggeagte here Lede van die Raad en Senaat van die P.U. vir C.H.O.,

Graag wens ek by hierdie geleentheid my innige dank teenoor $u$ te betuig vir die vertroue wat $u$ in my gestel het deur my tot Professor in Plantfisiologiese Navorsing te benoem. Waar hierdie verhoging van status groter verantwoordelikheid meebring, sal ek steeds trag om my plig met ywer en nougesetheid te vervul. Om die taak wat aan my opgedra is, te verrig op die grondslag en in die gees en gesindheid wat deur ons Inrigting voorgestaan word, sal steeds my strewe wees.

Hooggeleerde prof. dr. A. P. Goossens,

By hierdie geleentheid wens ek 'n besondere woord van dank en waardering tot $u$ te rig. Ek het my vorming as plantkundige in ' $n$ baie groot mate aan $u$ te danke. Eers het ek die geleentheid gehad om onder $u$ 
te studeer, en later het die voorreg my te beurt geval om in die Departement waarvan $u$ die hoof is, ' $n$ betrekking te aanvaar. Waar ons nou reeds jare lank saamwerk, kon ek steeds met die grootste vertroue na $u$ leiding opsien. Hoewel u my meerdere is, het ek tog ook steeds in $u$ ' $n$ goele vriend gehad, wat my belange op die hart gedra het en my met raad en daad bygestaan het. Dat ek nog altyd in dieselfde Departement met $u$ mag saamwerk, beskou ek as 'n groot voorreg.

Graag wens ek by hierdie geleentheid ook 'n woord van hartlike dank teenoor die Direkteur en Assistent-Direkteur van die Potchefstroomse Landboukollege, asook teenoor die hoofde en personeel van die Afdelings Weidingsnavorsing, Akkerbou en Skeikunde van dieselfde Inrigting uit te spreek. Waar ek in verband met my navorsing dikwels met die personeel van genoemde Afdelings in aanraking gekom het, het ek van hulle steeds 'n gees van groot welwillendheid en daadwerklike hulpvaardigheid ondervind. Tussen die Potchefstroomse Landboukollege en die P.U. vir C.H.O. bestaan daar ' $n$ baie goeie gees van samewerking. Graag wil ek die hoop uitspreek dat hierdie twee Inrigtings in die toekoms, in volksdiens, nog nouer mag saamwerk aan die oplossing van gemeenskaplike probleme.

Hooggeleerde here Professore, dames en here Lektore,

Ek beskou dit as ' $n$ besondere voorreg dat ek nou reeds ' $n$ geruime tyd lank onder $u$ kon werk. Die aangename kollegiale gees wat aan hierdie Inrigting heers, en die hulpvaardigheid en goedgesindheid wat ek steeds van $u$ ondervind het, het my altyd onder u laat tuis voel en is vir my in my werk 'n riem onder die hart. Ek kan u verseker dat ek altyd my bes sal doen om ywerig en getrou met u saam te werk en die belange van ons Inrigting te bevorder.

Dames en here Studente,

Waar ek met diegene onder u wat die Plantkunde bestudeer, gedurig in aanraking kom, hoop ek dat ons kennismaking nie tot die voorlesings 
en die practica beperk sal wees nie maar dat u die vrymoedigheid sal hê om te eniger tyd met u probleme na my te kom. Om $\mathfrak{u}$ in $u$ studie te lei en te help is nie alleen my plig nie; ek beskou dit ook as my aangename voorreg. Graag spreek ek die hoop uit dat $u$ studie in die Plantkunde nie bloot uit die opdoen van feitekennis sal bestaan nie, maar u ook diep onder die indruk van die wondere van die lewe sal bring.

Dames en here, ek dank u vir u welwillende aandag.

\section{AANGEHAALDE WERKE.}

1. Bergson, H. (1907): L'êvolution crêatice. F. Alcan, Parys. (Oorsig in Joad, 1948).

2. Bertalanffy, L. von (1932): Theoretische Biologie. Erster Band. Gebrüder Borntraeger, Berlyn.

3. (1949): Das Biologische Weltbilel. Erster Band. A. Francke, Bern.

4. Botha, P. J. (1948): The parasitism of Alectra vogelii Benth. with special reference to the germination of its seeds. J. S. Afr. Bot., 14:63-80.

5. (1950): The germination of the seeds of angiospermous root-parasites. 1. The nature of the changes occurring during pro-exposure of the seeds of Alectra vogelii Benth. Ibid., 16: 23-28.

II. The effect of time of pre-exposure, temperature of pre-exposure and concentration of the host factor on the germination of the secds of Alectra vogelii Benth. Ibid., 16:29-38.

6. (1951): The germination of the seeds of angiospermous root-parasites. III. The effect of time of exposure to the host factor on the germination of the seeds of Alectra vogelii Benth. Ibid., 17:49-58. IV. The properties and physiological significance of the host factor necessary for the germination of the seeds of Alectra vogelii Benth. Ibid., 17: 59-72.

7. Bruin, J. (1932): Het Christelijk Geloof en de Beocfening der Natumwetenschap. J. H. Kok, Kanpen.

8. Euler, H. von (1938): Bedeutung der Wirkstoffe (Ergone), Enzyme und Hilfstoffe im Zellenleben. Erg. Vitamin- und Hormonforschung, 1: 159.

9. Hartman, M. (1933): Allgemeine Biologie. Gustav Fischer, Jena.

10. Joad, C. E. M. (1948): Guide to Philosophy. V. Gollancz, London.

11. Lever, J. (1952): Het Creationisme. Gebr. Zomer en Keunings Uitgevermij. Wageningen.

12. —_ (1953): Sonjet-Biologie. Herdruk uit W'ugening's Hogeschoolblad.

13. Saunders, A. R. (1933): Studies in phanerogamic parasitism with particular reference to Striga lutea Lour. Wet. Painflet, 128, Staatsdrukker, Pretoria.

14. Smuts, J. C. (1927): Holism and Evolution. MacMillan, London. 